\title{
DEIXIS IN THE NOVEL THE KITE RUNNER BY KHALED HOSSEINI
}

\author{
Waladdin Panggabean ${ }^{1}$, Khusnul Khatimah ${ }^{2}$ \\ ${ }^{1}$ Balikpapan University \\ ${ }^{2}$ Universitas Muhammadiyah Kalimantan Timur \\ Email: waladdin@uniba-bpn.ac.id
}

\begin{abstract}
This research aims to identify the types of deixis used in the utterances in the novel The Kite Runner. The method used in this research is qualitative descriptive method because the data were analyzed in the form of words and utterances. The data were taken from the utterances which is uttered by the characters in the novel. The theory used in this research is Deixis theory by Stephen C. Levinson's, the result of this research shows that there are five types of deixis found in the novel The Kite Runner by Khaled Hosseini, those are: person deixis, place deixis, time deixis, discourse deixis, and social deixis. Based on the data deixis that have been found and analyzed by the researcher in this research, person deixis is more dominant used in the novel.
\end{abstract}

Keywords: Deixis; Novel; Utterance; Pragmatics.

\section{INTRODUCTION}

Novel is a kind of new prose containing a series of one's life stories with people around him/her by highlighting all actors' characters and demeanors. Novel contains many expressions of human thoughts, ideas, opinions, and messages presented in different characters' situation. The thought, ideas, opinions and messages within the novel write in text form which relates to a certain context. The text and context are defined differently, but those cannot be separated from the language. Text is written form while a context as an important for the hearer or addressee to understand what the speakers meaning. Context is broad sense, it means without context the addressee difficult to understand the meaning of speaker for whom, where, when, and how the sense occurs. So, to understand the text and context someone has to have linguistics skill or specifically pragmatics skill.

According to (Levinson, 1983)pragmatics is the study of the relationship between the language and the context, which is a basis in understanding the meaning of language. In line with this, pragmatics is the study of the aspect of the relationship between language and context that are relevant to the writing grammar. One of the issues within pragmatics study is 
features of the context of utterance or speech event, and thus also concerns ways in which the interpretation of utterances depends on the analysis of the context of utterance.

Moreover, (Rosmawaty, 2013) investigated deixis in the novel. The result of their research showed that the most dominant deixis found in that novel is personal deixis. It was related to the existence of characters as the deriving narrative and forming a storyline. They also found place deixis, time deixis, discourse deixis, and social deixisin the novel. (Ekowati, A., \& Sofwan, 2014) investigated deixis in conversation. The result of their study showed that pragmatics is something to do with context, and so is deixis. The use of deixis can carry implicit meaning to listeners. We need to seek the actual meaning of what a speaker says. Different circumstances lead people to have a different thought in their mind.

Novel, The Kite Runner, is one of the famous novels in America, an inspiring novel written by Khaled Hosseini. This inspirational novel is his first novel published in 2003 and has been adapted to the big screen in 2007. Behind that, the researcher also found reference and deixis phenomena of several parts of utterances that could be investigated by relating the utterances to the utterance's context and situation. This is in accordance with the pragmatic study of deixis which used by the researcher in reviewing and analysing the meaning and the references behind the utterances in language. The researcher limits the research problem with focuses on analyzing deixis in types and explains the references in the novel The Kite Runner. The purpose of this research is to identify, to classify deixis in types, and to explain references of the use of deixis. Therefore, the type of research used by the researcher in this research is a qualitative descriptive analysis research method.

\section{METHOD}

The type of research in this study is qualitative research, because the data were analysed in the form of words and utterances. Qualitative research is aimed at understanding social phenomena from the point of view of participants. This study employed a qualitative case study approach to explore students' in-depth, real-life experiences through detailed data collection (Creswell, J. W., \& Poth, 2018; Merriam, S. B., \& Tisdell, 2016). The source of data obtained from this study is based on primary and secondary source. The primary source is from the novel The Kite Runner by (Hosseini, 2003) with the number of pages 401. The secondary sources are from the books of Pragmatic by Levinson, the journals, the articles and the researcher collects other data sources from the internet.In the data collection procedure, first the researcher reads the novel and identifies deixis in the novel. After that, the researcher makes an inventory (register) of data deixis that obtained, then classify it to its types with the existing theory, Levinson's theory. Next, the researcher explains the references of data deixis that obtained and categorizes it into the appropriate type of reference with supporting theory by (Yule, 2000) in excerpts as final results according to the research questions.

\section{FINDINGS AND DISCUSSION}




\subsection{Findings}

The researcher in this research, found five types of deixis used in the novel The Kite Runner and found how the reference of the use of deixis used in the novel. The researcher mentioned one by one the number of types of deixis that are found.

\section{Types of Deixis used in the novel The Kite Runner.}

The researcher identifies and classifies the types of deixis that are found in the novel The Kite Runner by Khaled Hosseini. The result is five types of deixis used in the novel, person deixis, place deixis, time deixis, discourse deixis, and social deixis of sixty-seven data that have been analyzed. The researcher discusses the data of deixis one by one based on its types.

\section{Person Deixis}

The researcher identifies person deixis of the utterances in the novel The Kite Runner. Person deixis that used in the novel is divided into three cetegories, the first category, the second category, and the third category. It can be seen in the excerpts that discussed by the researcher below:

Rahim Khan laughed. "Children aren't coloring books. You don't get to fill them with your favorite colors." (The Kite Runner, p.24)

The excerpt states the researcher found the use of deixis person, the second category and the third category. It is conversation between Baba and Rahim Khan. The utterance said by Rahim Khan to Baba. The word "you" refers to interlocutor of Rahim Khan who is Baba, and the word "them" refers to children that showed in the previous utterance, "Children aren't coloring books". The excerpt below also deals with person deixis:

Four streets south of ours, I saw Omar, the son of an engineer who was a friend of Baba's. "I heard you won, Amir," he said. "Congratulations." "Thanks. Have you seen Hasan?" "Your Hazara?" I nodded. Omar headed the ball to his brother. "I hear he's a great kite runner." (The Kite Runner, p.75)

The excerpt wants to convey that the researcher found person deixis, the first category and the third category. It is conversation between Amir and Omar. The utterance said by Omar to Amir. They told about Hassan. The word "I" refers to Omar, and the word "he" refers to Hassan. The next excerpt is also person deixis:

Midmorning, General Taheri and his wife came. Soraya followed. We glanced at each other, looked away at the same time. "How are you, my friend?" General Taheri said, taking Baba's hand. Baba motioned to the IV hanging from his arm. Smiled thinly. The general smiled back. (The Kite Runner, p.173)

In the utterance above, the researcher found person deixis, the second category and the first category. The situation is General Taheri, his wife and his daughter, Soraya met Baba and 
Amir. The utterance said by General Taheri who started the conversation by greeting Baba. The word "you" in the utterance refers to Baba and the word "my" refers to General Taheri which it refers for itself. The next excerpt is also person deixis:

\section{Place Deixis}

The researcher identifies place deixis of the utterances in the novel The Kite Runner. Place deixis that are found in the novel refers to the place that the character is talking about. It can be seen in the excerpts that discussed by the researcher below:

Baba dozed off on the way, snoring like a jackhammer. I smelled tobacco on him and alcohol, sweet and pungent. But he sat up when I stopped the car and sain in a hoarse voice, "Keep driving to the end of the block." "Why Baba?" "Just go." He had me park at the south end of the street. He reached in his coat pocket and handed me a set of keys. "There," he said, pointing to the car in front of us. (The Kite Runner, p.144)

The excerpt wants to convey that the researcher found place deixis. The situation is Baba and Amir finished drink together. Suddenly, Baba asked Amir to go and gave him a set of keys. The word "there" refers to the place where Amir should go to the place which has been pointed of Baba, which is car. The next excerpt is also place deixis:

I think I already knew what he was going to say. "I want you to go to Kabul. I want you to bring Sohrab here," he said. "Please hear me. I know an American pair here in Peshawar, a husband and wife named Thomas and Betty Caldwell." (The Kite Runner, p.237)

The excerpt states the researcher found place deixis. It is the conversation between Amir and Rahim Khan at Rahim's house in Peshawar. The utterance said by Rahim Khan to Amir. The word "here" refers to the place where the conversation happens, that is Peshawar.

The man who let us in introduced himself as Zaman, the director of the orphanage. "I'll take you to my office," he said. "How many orphans live here?" Farid asked. "More than we have room for. About two hundred and fifty," Zaman said over his shoulder. (The Kite Runner, p.274)

The excerpt wants to convey that the conversation above contains place deixis. The situation is Amir and farid came to the orphanage in the northern part of Karteh-Seh. When they got there, they were welcomed by director of the orphanage. Then, the director invited them to his room. The utterance said by Farid. The word "here" refers to the place where Farid, Amir, and Zaman being and the conversation happened. It refers to the orphanage.

\section{Time Deixis}


The researcher identifies time deixis of the utterances in the novel The Kite Runner. Time deixis that are found in the novel refers to the time of something happens. It can be seen in the excerpts that discussed by the researcher below:

Something thumped next door. No, not next door, below. "What's that? Someone asked. "The others," Karim panted between labored breaths. "In the Basement." "How long have they been waiting?" Baba said, standing over Karim. "Two weeks." "I thought you said the truck broke down last week." Karim rubbed his throat. (The Kite Runner, p.129)

The excerpt states the researcher found time deixis. It is the conversation between Baba and Karim. The utterance said by character Baba to character Karim. The word "last week" refers to the time that explains the thing has been mentioned before, that is the truck that has been broken. The next excerpt is also time deixis

A sadness came over me. Returning to Kabul was like running into an old, forgotten friend and seeing that life hadn't been good to him, that he'd become homeless and destitute. "My father built an orphanage in Shar-e-Kohna, the old city, south of here," I said. "I remember it," Farid said. "It was destroyed a few years ago." (The Kite Runner, p.267)

The excerpt conveys that there's conversation between Farid and Amir about an orphanage built by Amir's father in Shar-e-Kohna. The utterance said by Farid. The word "A few years ago" refers to the time that explains what has been mentioned before, that is an orphanage built by Amir's father and has been destroyed. The next excerpt is also time deixis

"I'll tell you because I believe you. You have the look of a desperate man." He was quiet for a long time. "There's a Talib official," he muttered. "He visits once every month or two. He brings cash with him, not a lot, but better than nothing at all." His shifty eyes fell on me, rolled away. "Usually he'll take a girl. But not always." (The Kite Runner, p.277)

The excerpt states Amir and Farid visited the orphanage, and they met Zaman to find Amir's nephew, Sohrab. The Taliban supervised the orphanage. Zaman told that Taliban usually visited the orphanage once every month or two to checked the orphans live there. The word "every month or two" refers to the time when a Talib official visited the orphanage. The reference of time deixis in the utterance above is anaphora reference, because it refers to the information that has been mentioned before, about a time of an activity that is usually done.

\section{Discourse Deixis}

The researcher identifies discourse deixis of the utterances in the novel The Kite Runner. Discourse deixis that are found in the novel refers to the certain parts of the discourse that have been given or are being developed. It can be seen in the excerpts discussed by the researcher below: 
My favourite part of reading to Hassan was when we can across a big word that he didn't know. I'd tease him, expose his ignorance. One time, I was reading him a Mullah Nasrudin story and he stopped me. "What does that word mean?" "Which one? "Imbecile" "You don't know what it means?" I said, grinning. "Nay, Amir Agha." "But it's such a common word!" (The Kite Runner, p.31)

The excerpt wants to convey that the researcher found discourse deixis. It is the conversation between Amir and Hassan. The situation is, Amir reads the story to Hassan and in the middle, Hassan cuts his story and asks about the word which unfamiliar for him. The word "it" refers to the word "imbecile" This is next discourse deixis:

Buoyed by Rahim Khan's note, I grabbed the story and hurried downstairs to the foyer where Ali and Hassan were sleeping on a mattresss. That was the only time they slept in the house, when Baba was away and Ali had to watch over me. I shook Hassan awake and asked him if he wanted to hear a story. He rubbed his sleep-clogged eyes and stretched. "Now? what time is it?" "Never mind the time. This story's special. I wrote it myself," I whispered, hoping not to wake Ali. Hassan's face brightened. (The Kite Runner, p.36)

The excerpt states the researcher found discourse deixis. It is the conversation between Amir and Hassan. The situation is Amir comes to Hassan's room at night and awake him to listens his story that he writes. The word "it" refers to the word "story". The next excerpt is also discourse deixis:

"Inshallah, we'll celebrate later. Right now, I'm going to run that blue kite for you," he said. "Hassan!" I called. Come back with it!" He was already turning the street corner, his rubber boots kicking up snow. (The Kite Runner, p.73)

In the utterance above, the researcher found discourse deixis. The situation is Amir won the kite's competition but his blue kite was cut off and flew away. Hassan directly run for Amir's blue kite which flew away. The word "it" refers to the "blue kite".

\section{Social Deixis}

The researcher identifies social deixis of the utterances in the novel The Kite Runner. Social deixis that are found in the novel refers to the social differences of the role of participants. It can be seen in the excerpts that discussed by the researcher below:

When people scoffed that Baba would never marry well-after all, he was not of royal blood-he wedded my mother, Sofia Akrami, a highly educated woman universally regarded as one of Kabul's most respected, beautiful, virtuous ladies. And not only did she teach classic Farsi literature at the university, she was a descendant of the royal family, a fact that my father playfully rubbed in the skeptics' face by referring to her as "My Princess". (The Kite Runner, p.17) 
The excerpt wants to convey that Amir told about his mother whom his father loved. During his mother's life, his father always called her My Princess. The word "My Princess" in the excerpt is social deixis. The reason why his father called his mother like that because of the background of his mother's life that came from royal family, a highly educated woman that most respected in Kabul, beautiful, and virtuous ladies, while his father is not from royal blood like his mother.

\subsection{Discussion}

In the novel entitled Kite runner used as the source of the data, the writer find five types of deixis based on Levinson's theory; they are: Person Deixis, Temporal Deixis, Spatial Deixis, Discourse Deixis and Social Deixis. From the data above, the writer found that each types of deixis is found based on its changeable characteristics based on the context of the utterance which will be different in each different utterance and situation. The results of this research are slightly different from three other researches which is the research about deixis conducted by (Zaiman, 2011) only found three types of deixis and research conducted by (Nurani, 2016) found pronominals, nominals, and grammatical deixis. Meanwhile for research conducted by (Pratiwi, 2017) the types of deixis is found is person deixis which is third person pronoun be a dominant deixis that is found.

Second finding indicates the position of deixis in the novel. The position of deixis is found vary for each the class words, in the novel the writer found that there are deixis as pronoun, noun, adjective, adverb of place, and adverb of time. On research by (Zaiman, 2011), the positin of deixis is described as the used of deixis which are commonly as the subject meanwhile on this research, the position of deixis is varied according to the context and the use of the deixis itself in the utterance, possessive pronoun "My" for example in this research acts as adjective which is explain noun after the word.

\section{CONCLUSIONS}

Based on the data analyzed in this research, the researcher concludes that the types of deixis found in the novel The Kite Runner by Khaled Hosseini are Person Deixis, place time deixis, discourse, and social deixis. The type of deixis which is more dominant used in the novel is person deixis. Many characters in the novel use person deixis as replacements of their name and repeatedly continuously and more often so it makes person deixis more dominant in the novel than the other deixis. The use of place deixis is to showplace intended by the characters, the use of time deixis is to show time about something that happened, the use of discourse deixis is to show the event that being improved, and the use of social deixis is to show the social status of character in the novel The Kite Runner. Hosseini wished to express to his readers through his writings that success and victory are not the only factors that contribute to one's happiness; other factors include love, respect for others, loyalty, sympathy, and empathy. To synchronize the conclusion above, the researcher must convey to readers that when analyzing the character and theme, the researcher is fully aware of the researcher's lack of knowledge, enlightenment, and time to conduct accurate and flawless research on the characters, theme, and moral message in 'The Kite Runner' novel. Thus, the researcher anticipates that there will be 
readers who wish to delve deeper into the character, theme, and moral message of 'The Kite Runner'.

\section{REFERENCES}

Creswell, J. W., \& Poth, C. N. (2018). Qualitative inquiry \& research design: Choosing among five approaches (4th ed.). Sage Publications, Inc.

Ekowati, A., \& Sofwan, A. (2014). The use of pragmatic deixis in conversation texts in "Pathway to English. Lembaran Ilmu Kependidikan, 2(43), 71-77.

Hosseini, K. (2003). The Kite Runner. Afghan Mellat Online Library.

Levinson, S. C. (1983). Pragmatics. Cambridge University Press.

Merriam, S. B., \& Tisdell, E. J. (2016). Qualitative research: A guide to design and implementation (4th ed.). Jossey-Bass.

Nurani, \& H. (2016). Deixis in Taglines: A Socio-Cultural Semiotic Analysis. . Journal of English Language Teaching, 1, 77-89.

Pratiwi, S. (2017). Person Deixis in English Translation of Summarized Shahih Al-Bukhari Hadith in the Book of As-Salat. Advance in Language and Literary Studies, 9(1), 40-43.

Rosmawaty. (2013). Analysis of the Use of the Kind of Deixis on 'Ayat-Ayat Cinta' Novel by Habiburrahman El-Shirazy. International Journal of Humanities and Social Science, 3(17), 57-66.

Yule, G. (2000). Pragmatics (1st ed.). Oxford: Oxford University Press.

Zaiman. (2011). The Study of Personal, Place and Time Deixis In Jane Austen's Novel "Persuasion. The State Institute for Islamic Studies Jambi. 